\title{
Preface: How far has Neotropical Ichthyology progressed in twenty years?
}

\author{
José L. O. Birindelli1 and Brian L. Sidlauskas ${ }^{2}$
}

Studies on the diversity, taxonomy, phylogeny, and biogeography of Neotropical Fishes have thrived over the twenty years that have elapsed since the first symposium on their phylogeny and classification in Porto Alegre, Brazil. Here, we review recent advances in the study of Neotropical fishes and assess the known diversity of freshwater species in that region. 6,255 valid freshwater species have been discovered in the Neotropics so far, and we estimate that over 9,000 species will be known when the inventory is complete. We also summarize the events of the second Symposium on Phylogeny and Classification of Neotropical Fishes that took place last year in Londrina, Brazil. Along with invited talks on the biodiversity of all major groups of Neotropical fishes, a series of presentations on the development of fish collections, and numerous contributed talks, the meeting included a special session to honor Dr. Richard Vari, who was one of the most prolific and beloved members of our community.

Keywords: Biodiversity, Phylogeny, Systematics, Taxonomy, Richard Vari.

Estudos sobre diversidade, taxonomia, filogenia e biogeografia de peixes neotropicais prosperaram nos últimos vinte anos, desde o primeiro simpósio sobre filogenia e classificação em Porto Alegre, Brasil. Aqui, os novos avanços nos estudos de peixes neotropicais são discutidos e a diversidade conhecida reavaliada para espécies de água doce. Foram descobertas 6.255 espécies de peixes de água doce para na região Neotropical até o momento, e estimamos que haja mais de 9.000 espécies quando o inventário estiver completo. Nós resumimos as informações do segundo Simpósio sobre Filogenia e Classificação de Peixes Neotropicais ocorrido no ano passado em Londrina, Brasil. Além de apresentações de convidados sobre Biodiversidade dos grandes grupos de peixes Neotropicais, de uma série de apresentações sobre o estado da arte das coleções científicas, e de diversas outras apresentações, o simpósio incluíu uma sessão especial em homenagem ao Dr. Richard Vari, um dos membros mais prolíficos e amados da nossa comunidade.

Palavras-chave: Biodiversidade, Filogenia, Sistemática, Taxonomia, Richard Vari.

In 1997, 175 delegates from around the world convened in Porto Alegre for the first symposium on the phylogeny and classification of Neotropical fishes (Malabarba et al., 1998). Those participants led, discussed and published synthetic studies of the phylogeny, diversity and biogeography of South America's great ichthyofauna resulting from the incredible flowering of research on Neotropical Ichthyology that had begun in the previous two decades, and that has only accelerated since.

The authors of that original volume inhabited a scientific and analytical world based primarily on morphological data, with molecular studies just beginning to appear (Alves-Gomes et al., 1995; Ortí, Meyer, 1997; AlvesGomes, 1998; Farias et al., 1998). The first comprehensive and densely sampled molecular phylogenies of the major components of the Neotropical ichthyofauna (Calcagnotto et al., 2005; Sullivan et al., 2006; López-Fernández et al.,
2010; Tagliacollo et al., 2016) were still nearly a decade or more in the future. Researchers in 1998 worked as part of a relatively small community of scientists focused on Neotropical fishes, and studied primarily specimens housed in the collections of North America, Europe, and a few major South American research centers such as those at the Zoological Museum at the University of São Paulo, Brazil's National Museum in Rio de Janeiro, and the Biological Museum of the Central University of Venezuela in Caracas. While their science yielded unprecedented knowledge of Neotropical diversity, it also revealed large lacunae or uncertainties in our ability to infer the true number of species of fishes that inhabit the Neotropics, reconstruct the relationships of their cardinal lineages, understand their biogeographic history, or mitigate anthropogenic impacts on that marvelous diversity (Vari, Malabarba, 1998).

${ }^{1}$ Museu de Zoologia, Departamento de Biologia Animal e Vegetal, Universidade Estadual de Londrina, Rodovia Celso Garcia Cid 380 , 86057-970 Londrina, PR, Brazil. josebirindelli@yahoo.com, ○https://orcid.org/0000-0001-9646-9636 (corresponding author)

${ }^{2}$ Oregon State University, Department of Fisheries and Wildlife, 104 Nash Hall, Corvallis, 97331 Oregon, USA. brian.sidlauskas@ oregonstate.edu 
In their introduction to the 1998 volume, Richard Vari and Luiz Malabarba highlighted four "paramount initiatives" that could help address these gaps in knowledge: extensive ichthyofaunal surveys, expanded facilities and staff devoted to the curation of natural history collections, funding in support of wide scale revisionary and phylogenetic studies, and increased development of the specialized collections (e.g., tissue samples) needed for molecular systematics. The past twenty years have seen progress in all four initiatives, which has contributed to a huge expansion of ichthyological research in South America. For example, funding from agencies like Brazil's FAPESP and the United States' NSF supported major species inventories for catfishes and characiforms, which added hundreds of thousands of specimens and thousands of associated tissue to natural history collections, including many newly founded or rejuvenated across Latin America. Similarly, the Brazilian funding agencies CAPES and $\mathrm{CNPq}$ have supported scientific meetings, research projects and graduate programs that greatly expanded the number of professionals devoted to the care and use of fish collections. An increasingly diverse and numerous population of scientists curates those collections, studies their specimens and reports results at a prodigious and accelerating rate each year (Buckup et al., 2007; Ota et al., 2015). The journal that you are now reading was founded in 2003 in part to provide a suitable outlet for their productivity.

Despite such progress, our field has also seen setbacks, and we must continue to progress if we are to understand and document the diversity of fishes in time to help protect it from environmental degradation resulting from land use changes, infrastructure expansion and projected energy demands. Sadly, recent trends in funding and support are moving us in the opposite direction. Most notably and tragically, funding cuts and inadequate infrastructure at Brazil's National Museum and Butantan Institute resulted in major conflagrations and nearly complete loss of priceless and irreplaceable collections. Though no fish specimens were lost in these blazes, the tragedies illustrate the susceptibility of fish collections to similar catastrophe if institutions defer investment in infrastructure and upkeep. Insufficient funding and support also slows research and blocks the career advancement of talented young scientists, many of whom struggle to find permanent positions. As a critically important presentation authored by dozens of women at the 2017 meetings in Londrina pointed out, our field should not take our improved human diversity as evidence that we have achieved full equity and inclusion, particularly with respect to the representation of women among our colleagues at all levels (Slobodian et al.). We must continue to open opportunities to those with less privilege, and work to further build a community that supports, values and promotes diversity among the scientists who study and defend the diversity of fishes.

Through these triumphs and challenges, the field of Neotropical Ichthyology has advanced dramatically in the past 20 years. Morphological phylogenetic analyses have become larger and more comprehensive (Dillman et al., 2016; Mirande, 2018) or have delved into little explored character systems like those of the gas-bladder, muscles, pseudotympanum, sensory canals or ultrastructure of sperm (Di Dario, 2004; Birindelli et al., 2009; Datovo, Castro, 2012; Quagio-Grassiotto et al., 2012; Dutra et al. 2015). Molecular approaches have become widespread and even ubiquitous in their application with their phylogenetic results alternately challenging, expanding or affirming earlier osteological analyses (Oliveira et al., 2011; Lujan et al., 2015; Tagliacollo et al., 2016; Carvalho et al., 2018; Melo et al., 2018) and providing rich data with which to examine hypotheses of speciation (Barluenga, Meyer 2004; Pereira et al., 2011; Ramirez et al., 2017). New technologies like Illumina sequencing and Computed Tomography (CT) scanning have greatly expand our analytical possibilities. These bioinformatic tools afford us the ability to attempt phylogenetic reconstruction at the level of the genome (Ilves, López-Fernández, 2014; Arcila et al., 2017; Hughes et al., 2018), fly digitally through the skulls of rare, miniature and fossil taxa to discover previously inaccessible characters (Maldanis et al., 2016), and describe the morphological diversity of fishes mathematically and in all three dimensions (Carvalho, Albert, 2011; Evans et al., 2016). Analytical advances such as species tree methods, gene-genealogy interrogation, and the flowering of phylogenetic comparative methods complement the technological innovations by providing new ways of answering old questions about the interrelations of fishes, and by expanding the range of questions that we can ask about the evolution of the wonderful diversity of the Neotropics (Sidlauskas 2008; López-Fernández et al., 2014; Evans et al., 2016; Roxo et al., 2017). Exciting time to be a part of the ichthyological community!

Though we still have much to learn about the diversity of Neotropical fishes, we have come closer to answering some of the fundamental questions framed decades ago. In particular, our knowledge of Neotropical ichthyofauna (including freshwater and coastal marine species) now representing approximately $30 \%$ of the 35,000 known living fish species (Nelson et al., 2016; Fricke et al., 2018). The freshwaters of South and Central Americas currently harbor 6,255 known, valid species (Reis et al., 2003; Fricke et al., 2018) meaning that most of the Neotropical species are freshwater and endemic (Albert et al., 2011). Published estimates of the true number of freshwater species in Neotropical region have increased from 5,000 (Böhlke et al., 1978) to 8,000 (Schaefer, 1998) and then recently to 9,000 (Reis et al., 2016). However, these numbers are surely underestimates given that numbers of known fish species worldwide increases by approximately 390 per year, or 11\% each decade (Nelson et al., 2016; Fricke et al., 2018), with most newly discovered fishes originating in the Amazon and Paraná basins (Nelson et al., 2016). The rate of species described per year have more than doubled 
in the last twenty years, especially since the beginning of the new Millennium (Fig. 1). At the current pace, it will be decades before we hit an asymptote in the rate of species description, and approximately 70 years before the inventory might be considered essentially complete (Ota $e t$ al., 2015). At such point, the number of fish species in the freshwaters of South America should easily exceed 9,000 species (Fig. 1), as estimated using Jackknife 1 method in the Vegan package in R, specpool function (Oksanen et al., 2013) (Fig. 1). Though many of these undescribed species will be morphologically and genetically similar to already known species, some will undoubtedly reveal previously unknown morphological, ecological and genetic dimensions of Neotropical biodiversity. As shown clearly by the recent discovery of two species so morphologically distinct and genetically divergent that they prompted erection of entirely new families (Rodiles-Hernández et al., 2005; de Pinna, 2017), the Neotropics have not given up all their ichthyological secrets.

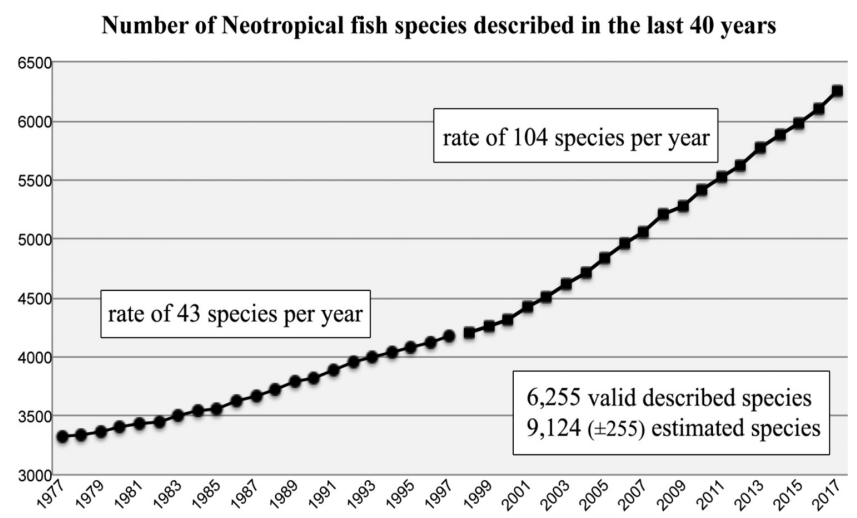

Fig. 1. Accumulative curve of valid freshwater species described by year from 1977 to 2017 (last 40 years) in the Neotropical region (based on Reis et al., 2003, and Fricke et al., 2018), showing an increased rate of species description in the beginning of the twenty-first century, and the estimate number of total valid species for the region based on Jackknife 1.

We have also advanced greatly in our knowledge of the phylogeny and evolution of Neotropical fishes, with recent molecular, morphological and combined studies frequently resolving stable reconstructions among families and genera within each order (Oliveira et al., 2011; Birindelli, 2014; Lujan et al., 2015; Lopez-Fernandez et al., 2010; Dillman et al., 2016; Tagliacollo et al., 2016; Ilves et al., 2018; Mirande, 2018; Carvalho et al., 2018). Yet, not all studies agree, and new data have challenged existing classifications (Covain et al., 2016), refined longstanding phylogenetic hypotheses (Melo et al., 2018) or identified recalcitrant nodes that challenge even the most current analyses (Ilves et al., 2018). Some of the most substantial uncertainty surrounds the resolution of the major lineages within Ostariophysi, with some molecular studies returning paraphyly of the two major characiform suborders or not recovering a sister relationship between Siluriformes and Gymnotiformes (Nakatani et al., 2011; Chakrabarty et al., 2016), as long supported by morphological data (Fink, Fink, 1981), and as also recovered by a prominent phylogenomic study (Arcila et al., 2017). Definitive resolution of such difficult and ancient nodes will require further study with increased taxon sampling, and perhaps improved analytical techniques.

At the other end of the scale, most Neotropical species have never been placed in phylogenetic context, and even phylogenies that appear to have near complete taxon sampling lack the myriad undescribed species that surely exist throughout the Neotropics. An even greater number of species have been coded for only morphological or only molecular data. It will require substantial effort by the entire Neotropical Ichthyology community to fill these gaps and thereby understand species-level phylogenetic relationships, especially those in high diversity genera in complex families such as Hypostomus (Loricariidae), and Astyanax (Characidae). We need more species-level phylogenetic studies and taxonomic revisions at broad geographic scales using combined morphological and molecular data, and predict that the next twenty years will see our community working diligently to fill that gap.

The world's community of scientists studying the diversity, taxonomy, phylogeny, and biogeography of Neotropical Fishes convened once again last October in Londrina (Paraná State, Brazil) for the second International Symposium on Phylogeny and Classification of Neotropical Fishes. During the meeting, they presented new hypotheses to the scientific community and discussed recent advances, particularly those pertaining to new methods. The event benefited from the presence of many professionals and graduate students (Fig. 2). Of the 264 total participants, approximately $40 \%$ were professionals, $40 \%$ graduate students, and $20 \%$ undergraduate students. Seventeen countries were represented, including 10 of the 13 South American countries. A total of 284 papers were presented, allocated into four sessions. In the Mini-Symposia, authors were invited to present synthetic research summarizing major advances in addressing the gaps identified twenty years ago. Vari's Legacy included 28 papers related to and honoring the work of the late Dr. Richard Vari, curator at the Smithsonian Institution, who was one of the most prolific and beloved members of our community, the author of more than 150 peer-reviewed papers and mentor to dozens of students and colleagues throughout South and North America (Sidlauskas et al., 2017). The papers presented during this session included new phylogenetic, evolutionary and revisionary work on groups on which Dr. Vari had focused substantial effort, such as Anostomoidea, Siluriformes and Gymnotiformes, as well as descriptions of new Neotropical species named in his honor. Other presentations and posters detailed his influence in building scientific capacity in Brazil, Colombia, Ecuador, Peru, 


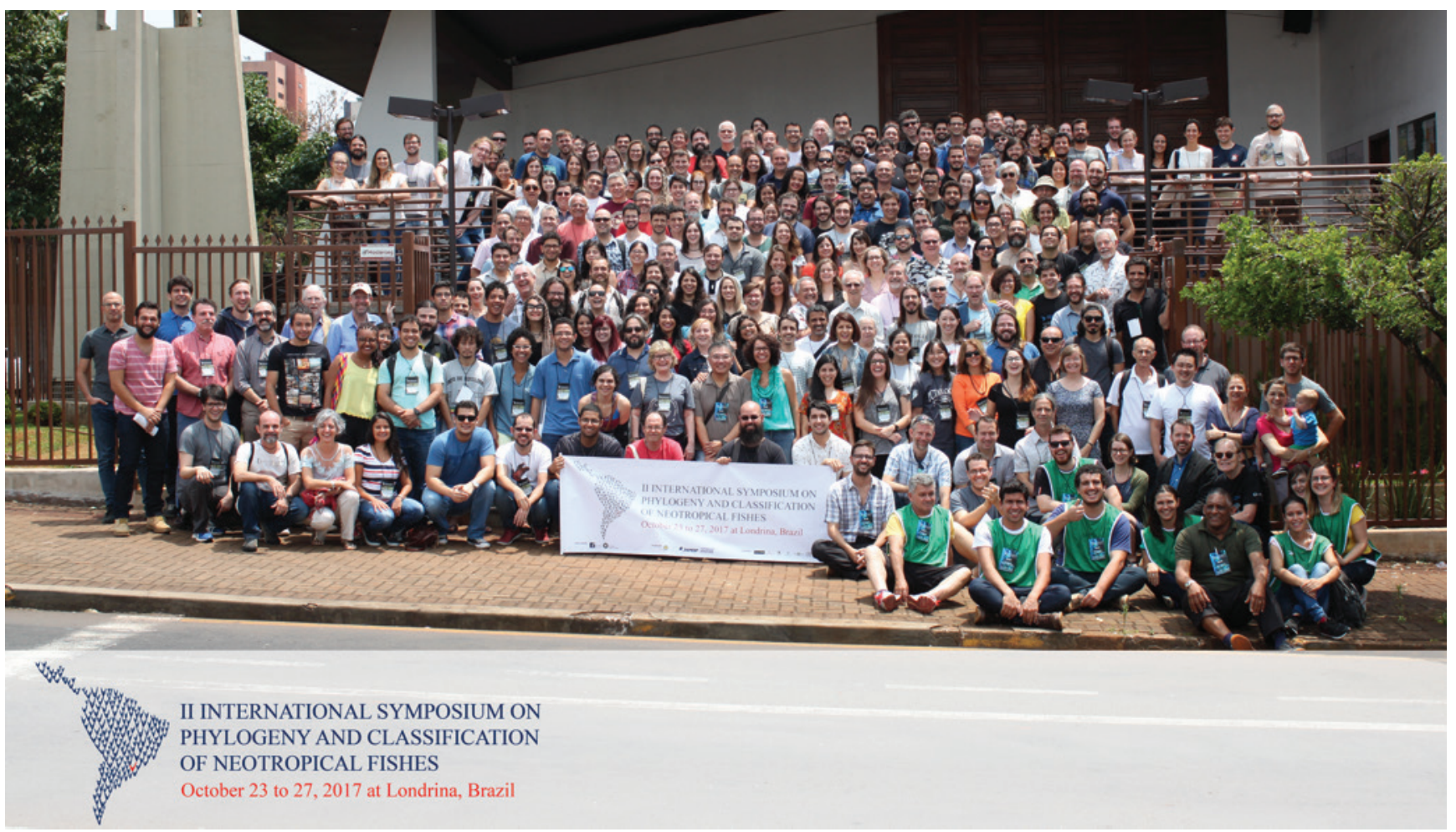

Fig. 2. Official group photograph of the II International Symposium on Phylogeny and Classification of Neotropical Fishes, taken in Londrina, Paraná state, Brazil, on October $25^{\text {th }}$, 2017, which included 238 of the 264 restriged participants.

Suriname, the United States, and Venezuela, and on links between his works on South American and African fishes. Most of the 28 presenters (from nine countries on three continents) had enjoyed the distinct privilege of working directly with Dr. Vari as visiting scientists at the Smithsonian, and several of the papers presented during the session resulted directly from those visits. Overall, it is impossible to overestimate Dr. Vari's importance to the development of Neotropical Ichthyology and the training of Neotropical Ichthyologists, or to fully catalogue the ways in which he enriched our community. The symposium and this special volume are dedicated to honoring his memory. A session on fish collections aimed to celebrate the growth of such resources and discuss the challenges in their upkeep and curation. Finally, the general session included 180 papers covering various fish groups and subjects in fish systematics.

While most papers presented in the Symposium still await publication, we present here in this special issue of Neotropical Ichthyology dedicated to papers presented in the Symposium. The contributions include the evolution and interrelationships of Otophysi (Arratia), reviews of primitive lineages of fishes based on fossils (Hilton, Lavoué; Ribeiro et al.), phylogenetic studies of major components of the Neotropical ichthyofauna based on molecular data (Arcila et al.; Bloom, Egan), or combined molecular and morphological data (Loureiro et al.). The contributions also include a history of biogeography of Amazonian fishes (Dagosta, de Pinna), a summary and new presentation of one of the most important hypotheses for the geological formation of the Amazon (Albert et al.) and a biogeographic hypothesis for fishes of the Brazilian coastal rivers (Thomaz, Knowles). Several others were recently published in other journals (Mirande, 2018; Henschel et al., 2018; Camelier et al., 2018; Melo et al., 2018) or as books (van der Sleen, Albert, 2017). Many others are in review or revision for publication in the pages of Neotropical Ichthyology or its sister journals in the years to come.

We have come a long way in the last twenty years, but there is still much to accomplish. We hope that our scientific community continues to grow and diversify, and predict that it will, for as long as Neotropical waters harbor such an incredible richness of fishes, there will be scientists willing to devote their careers to understanding and protecting that diversity. Through collaborative research, renewed support of science funding agencies, and the concerted effort of our community, our knowledge on the diversity and evolution of Neotropical fishes can increase more quickly than our capacity to destroy the world that they and we inhabit.

\section{Acknowledgements}

The assistance and trust of Carla S. Pavanelli (editor in chief), Luiz Roberto Malabarba (editor of this special issue) and all the editoral team of Neotropical Ichthyology journal made the publication of this special issue possible, and we are grateful for their support and sustained effort. We would like to also thank the organizing and scientific committees of the Symposium who organized the meeting, and selected and 
evaluated the papers presented, respectively. The organizing committee of the Symposium was composed of Claudio Oliveira, Carla Pavanelli, Fernanda Martins, Fernando Jerep, Lenice Souza-Shibatta, Lucia Giuliano-Caetano, Luiz Roberto Malabarba, Oscar Shibatta, and the scientific committee included Cristiano Moreira, Fabio Di Dario, Junior Chuctaya, Leonardo Ingenito, Marcelo Britto and Tiago Carvalho. The Symposium was only made possible due to the support of the Sociedade Brasileira de Ictiologia, represented by its board of directors, who approved our proposal and followed our work, and Universidade Estadual de Londrina, who provided logistical support, and inestimable human resources through the efforts of its technicians and students. Funding for the Symposium was provided by Coordenação de Aperfeiçoamento de Pessoal de Nível Superior (CAPES), Fundação de Amparo à Pesquisa do Estado de São Paulo (FAPESP), and the Smithsonian Institution, Washington, D.C. (SU), with the latter contribution making the special session on Vari's Legacy a reality. Richard Vari is no longer here to receive our thanks for sharing his steadfast support, gentle wisdom, tireless patience, and incredible intellect, but we can certainly thank Ann Vari for traveling so far to hear about the limitless ways in which her late husband improved our science and enriched our community, and for sharing him with us during their decades together. We thank the three plenary speakers (Luiz Malabarba, Lynne Parenti and Mario de Pinna) for their insightful historical perspectives and for helping us to highlight Vari's Legacy. We are also grateful to Hachimitsu for providing the petit fours for our morning coffee break, to Roberto Reis for providing Cerveja Cascuda for the opening ceremony, to Marcelo Melo for organizing a photography exhibit, and Rony Suzuki for preparing a planted aquarium with ornamental fishes for the entrance room. Finally, thanks are due to all participants in the Symposium, who contributed one way or another to the various discussions regarding Neotropical Fishes, and who made the Symposium a resounding success. We are greateful to Jon Fong (CAS) for kindly prodiving the numbers of species described from 2003 to 2017, and to João Fernando da Silva (UEL), who helped JLB with analyses in R.

\section{References}

Albert JS, Campos-da-Paz R. Phylogenetic systematics of American knifefishes: a review of the available data. In: Malabarba LR, Reis RE, Vari RP, Lucena ZMS, Lucena CAS, editors. Phylogeny and classification of Neotropical fishes. Porto Alegre: Edipucrs; 1998. p.409-438.

Albert JS, Petry PA, Reis RE. Major biogeographic and phylogenetic patterns. In: Albert JS, Reis RE, editors. Historical biogeography of Neotropical freshwater fishes. California: University of California Press; 2011. p.21-57.

Almeida-Toledo LD. Cytogenetic markers in neotropical freshwater fishes. In: Malabarba LR, Reis RE, Vari RP, Lucena ZMS, Lucena CAS, editors. Phylogeny and Classification of Neotropical Fishes. Porto Alegre: Edipucrs; 1998. p.583-588.
Alves-Gomes JA. The phylogenetic position of the South American electric fish genera Sternopygus and Archolaemus (Ostariophysi: Gymnotiformes) according to $12 \mathrm{~S}$ and $16 \mathrm{~S}$ mitochondrial DNA sequences. In: Malabarba LR, Reis RE, Vari RP, Lucena ZMS, Lucena CAS, editors. Phylogeny and Classification of Neotropical Fishes. Porto Alegre: Edipucrs; 1998. p.447-460.

Alves-Gomes JA, Ortí G, Haygood M, Heiligenberg W, Meyer A. Phylogenetic analysis of the South American electric fishes (order Gymnotiformes) and the evolution of their electrogenic system: a synthesis based on morphology, electrophysiology, and mitochondrial sequence data. Mol Biol Evol [serial on the Internet]. 1995; 12(2):298-318. Available from: https:// doi.org/10.1093/oxfordjournals.molbev.a040204

Arcila D, Ortí G, Vari RP, Armbruster JW, Stiassny ML, Ko KD, Sabaj MH, Lundberg J, Revell LJ, Betancur-R R. Genomewide interrogation advances resolution of recalcitrant groups in the tree of life. Nat Ecol Evol. 2017; 1(0020).

Barluenga M, Meyer A. The Midas cichlid species complex: incipient sympatric speciation in Nicaraguan cichlid fishes?. Mol Ecol [serial on the Internet]. 2004; 13(7):206176. Available from: https://doi.org/10.1111/j.1365294X.2004.02211.x

Birindelli JL. Phylogenetic relationships of the South American Doradoidea (Ostariophysi: Siluriformes). Neotrop Ichthyol [serial on the Internet]. 2014; 12(3):451-564. Available from: http://dx.doi.org/10.1590/1982-0224-20120027

Birindelli JL, Sousa LM, Sabaj-Pérez MH. Morphology of the gas bladder in thorny catfishes (Siluriformes: Doradidae). Proc Acad Nat Sci Phila [serial on the Internet]. 2009; 1:26196. Available from: https://www.jstor.org/stable/27667808

Böhlke JE, Weitzman SH, Menezes NA. Estado atual da sistemática dos peixes de água doce da América do Sul. Acta Amazon [serial on the Internet]. 1978; 8(4):657-77. Available from: http://dx.doi.org/10.1590/1809-43921978084657

Buckup PA. Relationships of the Characidiinae and phylogeny of characiform fishes (Teleostei: Ostariophysi). In: Malabarba LR, Reis RE, Vari RP, Lucena ZMS, Lucena CAS, editors, Phylogeny and Classification of Neotropical Fishes. Porto Alegre: Edipucrs; 1998. p.123-144.

Buckup PA, Menezes NA, Ghazzi MS, editores. Catálogo das espécies de peixes de água doce do Brasil. Rio de Janeiro: Museu Nacional; 2007. (Série livros; 23).

Calcagnotto D, Schaefer SA, DeSalle R. Relationships among characiform fishes inferred from analysis of nuclear and mitochondrial gene sequences. Mol Phylogenet Evol [serial on the Internet]. 2005; 36(1):135-53.Available from: https:// doi.org/10.1016/j.ympev.2005.01.004

Camelier P, Menezes NA, Costa-Silva GJ, Oliveira C. Molecular phylogeny and biogeographic history of the Neotropical tribe Glandulocaudini (Characiformes: Characidae: Stevardiinae). Neotrop Ichthyol [serial on the Internet]. 2018; 16(1):e 170157. Available from: http://dx.doi.org/10.1590/19820224-20170157

Carvalho TP, Albert JS. Redescription and phylogenetic position of the enigmatic Neotropical electric fish Iracema caiana 
Triques (Gymnotiformes: Rhamphichthyidae) using x-ray computed tomography. Neotrop Ichthyol [serial on the Internet]. 2011; 9(3):457-69. Available from: http://dx.doi. org/10.1590/S1679-62252011000300001

Carvalho TP, Arce M, Reis RE, Sabaj MH. Molecular phylogeny of Banjo catfishes (Ostaryophisi: Siluriformes: Aspredinidae): A continental radiation in South American freshwaters. Mol Phylogenet Evol [serial on the Internet]. 2018; 127:459-67. Available from: https://doi.org/10.1016/j.ympev.2018.04.039

Chakrabarty P, Faircloth BC, Alda F, Ludt WB, Mcmahan CD, Near TJ, Dornburg A, Albert JS, Arroyave J, Stiassny MLJ, Sorenson L, Alfaro ME. Phylogenomic systematics of ostariophysan fishes: ultraconserved elements support the surprising non-monophyly of Characiformes. Syst Biol [serial on the Internet]. 2017; 66(6):881-95. Available from: https:// doi.org/10.1093/sysbio/syx038

Covain R, Fisch-Muller S, Oliveira C, Mol JH, Montoya-Burgos JI, Dray S. Molecular phylogeny of the highly diversified catfish subfamily Loricariinae (Siluriformes, Loricariidae) reveals incongruences with morphological classification. Mol Phylogenet Evol [serial on the Internet]. 2016; 94(part B):492-517. Available from: https://doi.org/10.1016/j. ympev.2015.10.018

Datovo A, Castro RMC. Anatomy and evolution of the mandibular, hyopalatine, and opercular muscles in characiform fishes (Teleostei: Ostariophysi). Zoology [serial on the Internet]. 2012; 115(2):84-116. Available from: https://doi.org/10.1016/j. zool.2011.09.008

Di Dario F. Homology between the recessus lateralis and cephalic sensory canals, with the proposition of additional synapomorphies for the Clupeiformes and the Clupeoidei. Zool J Linn Soc [serial on the Internet]. 2004; 141(2):25770. Available from: https://doi.org/10.1111/j.10963642.2004.00122.x

Dillman CB, Sidlauskas BL, Vari RP. A morphological supermatrixbased phylogeny for the Neotropical fish superfamily Anostomoidea (Ostariophysi: Characiformes): phylogeny, missing data and homoplasy. Cladistics [serial on the Internet]. 2016; 32(3):276-96. Available from: https://doi.org/10.1111/ cla. 12127

Dutra GM, Jerep FC, Vari RP, Santana CD. The pseudotympanum in the Gymnotiformes (Teleostei, Ostariophysi, Otophysi): homology and evolution of a previously unexplored system in Neotropical electric fishes. Zool J Linn Soc [serial on the Internet]. 2015; 174(1):114-29. Available from: https://doi. org/10.1111/zoj.12221

Evans KM, Waltz B, Tagliacollo V, Chakrabarty P, Albert JS. Why the short face? Developmental disintegration of the neurocranium drives convergent evolution in neotropical electric fishes. Ecol Evol [serial on the Internet]. 2017; 7(6):1783-801. Available from: https://doi.org/10.1002/ece3.2704

Farias IP, Schneider H, Sampaio I. Molecular phylogeny of neotropical cichlids: the relationships of cichlasomines and heroines. In: Malabarba LR, Reis RE, Vari RP, Lucena ZMS, Lucena CAS, editors. Phylogeny and Classification of Neotropical Fishes. Porto Alegre: Edipucrs; 1998. p.499-508.
Fink SV, Fink WL. Interrelationships of the ostariophysan fishes (Teleostei). Zool J Linn Soc [serial on the Internet]. 1981; 72(4):297-353. Available from: https://doi. org/10.1111/j.1096-3642.1981.tb01575.x

Fricke R, Eschmeyer WN, van der Laan R, editors. 2018. Catalog of Fishes: genera, species, references. (http://researcharchive. calacademy.org/research/ichthyology/catalog/fishcatmain. asp). Electronic version accessed 20 Sept 2018.

Gayet M, Meunier FJ. Maastrichtian to early late Paleocene freshwater Osteichthyes of Bolivia: additions and comments. In: Malabarba LR, Reis RE, Vari RP, Lucena ZMS, Lucena CAS, editors. Phylogeny and Classification of Neotropical Fishes. Porto Alegre: Edipucrs; 1998. p.85-110.

Henschel E, Mattos JLO, Katz AM, Costa WJEM. Position of enigmatic miniature trichomycterid catfishes inferred from molecular data (Siluriformes). Zool Scr [serial on the Internet]. 2018; 47(1):44-53. Available from: https://doi.org/10.1111/ zsc. 12260

Hughes LC, Ortí G, Huang Y, Sun Y, Baldwin CC, Thompson AW, Arcila D, Betancur-R R, Li C, Becker L, Bellora N, Zhao XM, Li XF, Wang M, Fang C, Xie B, Zhou ZC, Huang H, Chen SG, Venkatesh B, Shi Q. Comprehensive phylogeny of ray-finned fishes (Actinopterygii) based on transcriptomic and genomic data. Proc Acad Nat Sci Phila [serial on the Internet]. 2018; 115(24):6248-54. Available from: https://doi.org/10.1073/ pnas. 1719358115 .

Ilves KL, López-Fernández H. A targeted next-generation sequencing toolkit for exon-based cichlid phylogenomics. Mol Ecol Resour [serial on the Internet]. 2014; 14(4):802-11. Available from: https://doi.org/10.1111/1755-0998.12222

Ilves KL, Torti D, López-Fernández H. Exon-based phylogenomics strengthens the phylogeny of Neotropical cichlids and identifies remaining conflicting clades (Cichliformes: Cichlidae: Cichlinae). Mol Phylogenet Evol [serial on the Internet]. 2018; 118:232-43. Available from: https://doi.org/10.1016/j. ympev.2017.10.008

Kullander SO. A phylogeny and classification of the South American Cichlidae (Teleostei: Perciformes). In: Malabarba LR, Reis RE, Vari RP, Lucena ZMS, Lucena CAS, editors. Phylogeny and Classification of Neotropical Fishes. Porto Alegre: Edipucrs; 1998. p.461-498.

López-Fernández H, Winemiller KO, Honeycutt RL. Multilocus phylogeny and rapid radiations in Neotropical cichlid fishes (Perciformes: Cichlidae: Cichlinae). Mol Phylogenet Evol [serial on the Internet]. 2010; 55(3):1070-86. Available from: https://doi.org/10.1016/j.ympev.2010.02.020

López-Fernández H, Arbour JH, Winemiller KO, Honeycutt RL. Testing for ancient adaptive radiations in Neotropical cichlid fishes. Evolution [serial on the Internet]. 2013; 67(5):1321-37. Available from: https://doi.org/10.1111/evo.12038

Lujan NK, Armbruster JW, Lovejoy NR, López-Fernández H. Multilocus molecular phylogeny of the suckermouth armored catfishes (Siluriformes: Loricariidae) with a focus on subfamily Hypostominae. Mol Phylogenet Evol [serial on the Internet]. 2015; 82(part A):269-88. Available from: https://doi. org/10.1016/j.ympev.2014.08.020 
Lundberg JG. The temporal context for the diversification of Neotropical fishes. In: Malabarba LR, Reis RE, Vari RP, Lucena ZMS, Lucena CAS, editors. Phylogeny and Classification of Neotropical Fishes. Porto Alegre: Edipucrs; 1998. p.49-68.

Lundberg JG, Marshall LG, Guerrero J, Horton B, Malabarba MC, Wesselingh F. The stage for Neotropical fish diversification: a history of tropical South American rivers. In: Malabarba LR, Reis RE, Vari RP, Lucena ZMS, Lucena CAS, editors. Phylogeny and Classification of Neotropical Fishes. Porto Alegre: Edipucrs; 1998. p.27-48.

Malabarba MC. Phylogeny of fossil Characiformes and paleobiogeography of the Tremembé formation, São Paulo, Brazil. In: Malabarba LR, Reis RE, Vari RP, Lucena ZMS, Lucena CAS, editors. Phylogeny and Classification of Neotropical Fishes. Porto Alegre: Edipucrs; 1998. p.69-84.

Malabarba LR, Reis RE, Vari RP, Lucena ZM, Lucena CAS, editors. Phylogeny and classification of neotropical fishes. Porto Alegre: Edipucrs; 1998.

Maldanis L, Carvalho M, Almeida MR, Freitas FI, Andrade JAFG, Nunes RS, Rochitte CE, Poppi RJ, Freitas RO, Rodrigues F, Siljeström S, Lima FA, Galante D, Carvalho IS, Perez CA, Carvalho MR, Bettini J, Fernandez V, Xavier-Neto J. Heart fossilization is possible and informs the evolution of cardiac outflow tract in vertebrates. Elife [serial on the Internet]. 2016; 5:e14698. Available from: https://doi.org/10.7554/eLife.14698

Melo BF, Sidlauskas BL, Hoekzema K, Vari RP, Dillman CB, Oliveira C. Molecular phylogenetics of Neotropical detritivorous fishes of the family Curimatidae (Teleostei: Characiformes). Mol Phylogenet Evol [serial on the Internet]. 2018; 127:800-12. Available from: https://doi.org/10.1016/j.ympev.2018.06.027

Mirande JM. Morphology, molecules and the phylogeny of Characidae (Teleostei, Characiformes). Cladistics [serial on the Internet]. 2018; 0:1-19.Available from: https://doi.org/10.1111/ cla. 12345

Nakatani M, Miya M, Mabuchi K, Saitoh K, Nishida M. Evolutionary history of Otophysi (Teleostei), a major clade of the modern freshwater fishes: Pangaean origin and Mesozoic radiation. BMC Evol Biol [serial on the Internet]. 2011; 11(177):1-25. Available from: https://doi.org/10.1186/1471-2148-11-177

Nelson JS, Grande T, Wilson MVH. 2016. Fishes of the World. 5th ed. Hoboken (NJ): J. Wiley; 2016

Oksanen J, Blanchet FG, Kindt R, Legendre P, Minchin PR, O'Hara $\mathrm{RB}$, et al. Vegan: Community Ecol- ogy Package. R package version 2.0-8. 2013. Available: http://CRAN.R-project.org/ package $=$ vegan

Oliveira C, Avelino GS, Abe KT, Mariguela TC, Benine RC, Ortí G, Vari RP, Castro RM. Phylogenetic relationships within the speciose family Characidae (Teleostei: Ostariophysi: Characiformes) based on multilocus analysis and extensive ingroup sampling. BMC Evol Biol [serial on the Internet]. 2011; 11(275):1-25. Available from: https://doi.org/10.1186/14712148-11-275

Ortí G, Meyer A. The radiation of characiform fishes and the limits of resolution of mitochondrial ribosomal DNA sequences. Syst Biol [serial on the Internet]. 1997; 46(1):75-100. Available from: https://doi.org/10.1093/sysbio/46.1.75
Ota RR, Message HJ, Graça WJ, Pavanelli CS. Neotropical siluriformes as a model for insights on determining biodiversity of animal groups. PloS One [serial on the Internet]. 2015; 10(7):e0132913. Available from: https://doi.org/10.1371/ journal.pone.0132913

Pereira LHG, Pazian MF, Hanner R, Foresti F, Oliveira C. DNA barcoding reveals hidden diversity in the Neotropical freshwater fish Piabina argentea (Characiformes: Characidae) from the Upper Paraná Basin of Brazil. Mitochondrial DNA [serial on the Internet]. 2011; 22(sup1):87-96.Available from: https://doi.org/10.3109/19401736.2011.588213

de Pinna MCC. Phylogenetic relationships of neotropical Siluriformes: Historical overview and synthesis of hypotheses. In: Malabarba LR, Reis RE, Vari RP, Lucena ZMS, Lucena CAS, editors, Phylogeny and Classification of Neotropical Fishes. Porto Alegre: Edipucrs; 1998. p.279-330.

de Pinna MCC, Zuanon JA, Rapp Py-Daniel LH, Petry P. A new family of neotropical freshwater fishes from deep fossorial Amazonian habitat, with a reappraisal of morphological characiform phylogeny (Teleostei: Ostariophysi). Zool J Linn Soc [serial on the Internet]. 2017; 182(1):76-106. Available from: https://doi.org/10.1093/zoolinnean/zlx028

Quagio-Grassiotto I, Malabarba LR, Azevedo MA, Burns JR, Baicere-Silva CM, Quevedo R. Unique derived features in spermiogenesis and sperm morphology supporting a close relationship between the species of Hollandichthys and Rachoviscus (Characiformes: Characidae). Copeia [serial on the internet]. 2012; 2012(4):609-25. Available from: https:// doi.org/10.1643/CG-11-171

Ramirez JL, Birindelli JL, Carvalho DC, Affonso PRAM, Venere PC, Ortega H, Carrillo-Avila M, Rodríguez-Pulido JA, Galetti PM, Jr. Revealing hidden diversity of the underestimated neotropical ichthyofauna: DNA barcoding in the recently described genus Megaleporinus (Characiformes: Anostomidae). Front Genet [serial on the Internet]. 2017; 8:149. Available from: https:// doi.org/10.3389/fgene.2017.00149

Reis RE, Kullander SO, Ferraris CJ, Jr., organizers. Check list of the freshwater fishes of South and Central America. Porto Alegre: Edipucrs; 2003.

Reis RE, Albert JS, Di Dario F, Mincarone MM, Petry P, Rocha LA. Fish biodiversity and conservation in South America. J Fish Biol. 2016 Jul;89(1):12-47.

Rodiles-Hernández R, Hendrickson DA, Lundberg JG, Humphries JM. Lacantunia enigmatica (Teleostei: Siluriformes) a new and phylogenetically puzzling freshwater fish from Mesoamerica. Zootaxa [serial on the Internet]. 2005; 1000(1):1-24. Available from: http://dx.doi.org/10.11646/zootaxa.1000.1.1

Roxo FF, Lujan NK, Tagliacollo VA, Waltz BT, Silva GS, Oliveira C, Albert JS. Shift from slow-to fast-water habitats accelerates lineage and phenotype evolution in a clade of Neotropical suckermouth catfishes (Loricariidae: Hypoptopomatinae). PloS One [serial on the Internet]. 2017; 12(6):e0178240. Available from: https://doi.org/10.1371/journal.pone.0178240

Schaefer SA. Conflict and Resolution: Impact of New Phylogenetic Studies of the Neotropical Cascudinhos (Siluroidei; Loricariidae). In: Malabarba LR, Reis RE, Vari 
RP, Lucena ZMS, Lucena CAS, editors. Phylogeny and Classification of Neotropical Fishes. Porto Alegre: Edipucrs; 1998. p.375-401.

Sidlauskas B. Continuous and arrested morphological diversification in sister clades of characiform fishes: a phylomorphospace approach. Evolution [serial on the Internet]. 2008; 62(12):3135-56. Available from: https://doi.org/10.1111/ j.1558-5646.2008.00519.x

Sidlauskas BL, Ferraris C, Funk V, Parenti LR, de Pinna MCC, Reid GM. In Memoriam: Richard Peter Vari (August 24, 1949January 15, 2016). Copeia. 2017; 105(1):147-60.

van der Sleen P, Albert JS, editors. Field Guide to the Fishes of the Amazon, Orinoco, and Guianas. Princeton (NJ): Princeton University Press; 2017.

Sullivan JP, Lundberg JG, Hardman M. A phylogenetic analysis of the major groups of catfishes (Teleostei: Siluriformes) using rag1 and rag2 nuclear gene sequences. Mol Phylogenet Evol [serial on the Internet]. 2006; 41(3):636-62. Available from: https://doi.org/10.1016/j.ympev.2006.05.044
Tagliacollo VA, Bernt MJ, Craig JM, Oliveira C, Albert JS. Model-based total evidence phylogeny of Neotropical electric knifefishes (Teleostei, Gymnotiformes). Mol Phylogenet Evol [serial on the Internet]. 2016; 95:20-33. Available from: https:// doi.org/10.1016/j.ympev.2015.11.007

Vari RP, Harold AS. The genus Creagrutus (Teleostei: Characiformes: Characidae): monophyly, relationships, and undetected diversity. In: Malabarba LR, Reis RE, Vari RP, Lucena ZMS, Lucena CAS, editors. Phylogeny and Classification of Neotropical Fishes. Porto Alegre: Edipucrs; 1998. p.245-260.

Vari RP, Malabarba LR. Neotropical Ichthyology: an overview. In: Malabarba LR, Reis RE, Vari RP, Lucena ZMS, Lucena CAS, editors. Phylogeny and Classification of Neotropical Fishes. Porto Alegre: Edipucrs; 1998. p.1-12.

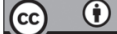

Submitted September 01, 2018 Accepted September 25, 2018 by Carla Simone Pavanelli 